Meta

Journal des traducteurs

Translators' Journal

\title{
Citations as Knowledge-rich Contexts: The Case of Semantic Markers
}

\section{Tanja Collet}

Volume 60, numéro 2, août 2015

$60^{\mathrm{e}}$ anniversaire. Les horizons de la traduction : retour vers le futur $60^{\text {th }}$ Anniversary. Translation's Horizons: Back to the Future

60mo aniversario. Los horizontes de la traducción: regreso al futuro

URI : https://id.erudit.org/iderudit/1032871ar

DOI : https://doi.org/10.7202/1032871ar

Aller au sommaire du numéro

Éditeur(s)

Les Presses de l’Université de Montréal

ISSN

0026-0452 (imprimé)

1492-1421 (numérique)

Découvrir la revue

Citer ce document

Collet, T. (2015). Citations as Knowledge-rich Contexts: The Case of Semantic Markers. Meta, 60(2), 320-320. https://doi.org/10.7202/1032871ar d'utilisation que vous pouvez consulter en ligne.

https://apropos.erudit.org/fr/usagers/politique-dutilisation/ 


\title{
Citations as Knowledge-rich Contexts: The Case of Semantic Markers
}

\author{
Tanja Collet \\ University of Windsor, Windsor, Canada \\ tcollet@uwindsor.ca
}

Citations have multiple functions in specialised discourse. They acknowledge intellectual indebtedness, partake in the social construction of knowledge, and enhance the text's overall persuasiveness. Citations can, furthermore, be engaged in meaning construal and serve to negotiate term meaning within the confines of the text. In this role, citations become a device for tracing semantic indebtedness by identifying similar or identical usages, or for signalling how the writer's intended meaning for a particular term deviates from the one, sometimes more canonical, constructed by others in their texts. Inserted during the process of text creation, these reported passages or text fragments may define or explain term meaning, or may simply relate partial semantic information pertaining to the term, such as its etymology, synonyms or hyponyms. In the new text, these passages acquire a dual dialogic quality: as citations, they participate in the social construction of knowledge by engaging in a "dialogue" with the writers of the previous texts but, as semantic markers, they also interact with the text's readers by responding to plausible needs for semantic clarification.

Citations that act as semantic markers bear a resemblance to knowledge-rich contexts. Indeed, like knowledge rich-contexts, they express conceptual information, i.e., information that can be used by a language specialist, such as a translator or terminologist, to acquire domain knowledge for a term. The semantic marker below, which focuses on the concept of reiteration, is a case in point:

Shifts within this particular reiteration chain may also have a more global impact on the target-text reception, as reiteration or recurrence, to use de Beaugrande and Dressler's (1981) term, is a textual feature "used to assert and reaffirm one's viewpoint" (de Beaugrande and Dressler 1981: 55). (Meta 2011 56(4): 767-768)

The paper's main aim is to define semantic markers as a specific type of knowledgerich context, and to propose a classification of semantic markers based on data extracted from a corpus of academic writings in the area of translation studies which appeared, between 2001 and 2011, in Meta: Journal des traducteurs / Meta: Translators' Journal.

Tanja Collet is an Associate Professor of Linguistics in the French Studies program at the University of Windsor, where she lectures in Applied Linguistics, Translation and Lexicology / Terminology. Her research interests concern the intersection between terminology, text linguistics and LSP, with a main focus on term-text dynamics in specialised discourse. Publications of note which form the basis of her current research include the following: (2013, forthcoming) "Obstacles lexico-sémantiques à la lecture réussie d'un texte de spécialité," TTR, XXVI(2) winner of the Prix Vinay et Darbelnet; and (2009) "La manière de signifier du terme en discours," Meta, 54(2). 